\author{
Mariola Walczak-Mikołajczakowa \\ UAM \\ mawal@amu.edu.pl
}

\title{
Jak Joan został Iwanem? \\ (O zmianach w bułgarskiej antroponimii okresu odrodzenia narodowego)
}

\begin{abstract}
AвSTRACт: Walczak-Mikołajczakowa Mariola, Jak Joan został Iwanem? (O zmianach w bułgarskiej antroponimii okresu odrodzenia narodowego) (How Joan Became Ivan [About Changes in the Bulgarian Anthroponymy from the Bulgarian National Revival Period]). „Poznańskie Studia Slawistyczne" 8. Poznań 2015. Publishing House of the Poznań Society for the Advancement of the Arts and Sciences, pp. 367-376. ISSN 2084-3011.

The article depicts reflection over the issue of changes in the Bulgarian anthroponymy from the Bulgarian National Revival period, which usually consists in an inconsistent, i.e. concerning only several historical figures, substitution of the Greek form Joan by the native form- Ivan. Furthermore, the author does not comprehensively answer the questions how and why it happened, although they present the issue as a complex one and possible to conceptualize in myriad ways.
\end{abstract}

KEYwORDS: anthroponymy; native and borrowed names; national revival

Do zastanowienia się nad tytułowym pytaniem zmusiły mnie pewne wątpliwości zgłoszone przez znajomą Bułgarkę. Problem sformułowany był wprost: „Czy patrząc z pozycji obcokrajowca na naszą historię, powiesz mi, dlaczego w szkole, którą kończyłam, uczono mnie, że nasi carowie nosili imiona Joan (Joan Asen, Joan Sziszman itp.), że nasz największy święty miał też tak na imię, ale wszędzie czytam o Iwanie Asenie, Iwanie Aleksandrze i o św. Iwanie Rylskim?".

Wydaje się, że nie jest to błaha kwestia i wymaga namysłu, skoro wciąż intryguje Bułgarów takich jak moja znajoma - dobrze wykształconych, o dużych walorach intelektualnych. Problem dotyczący stosunku do imion własnych poruszyła Elżbieta Solak w monografii Znaki szczególne. Językowe $i$ wokóljęzykowe problemy bułgarskiego Odrodzenia (Solak 2009) i chociaż kompendium to nie przynosi konkretnej odpowiedzi 
na zadane wyżej pytanie, to jednak omawia ważne zagadnienie związane z problemem rodzimości imion:

\begin{abstract}
Osobowe imię własne, kumulujące wiele funkcji, odczytywane przez pryzmat określonej kultury, może stanowić istotną wskazówkę na temat systemu wartości, zwyczajów, sposobu życia, religii itd. jego nosiciela, zawsze odniesionego do jakiejś grupy społecznej (lub subkultury). $Z$ drugiej strony nie mniej interesująca jest sama owa świadomość - system kategoryzacji (czy po prostu klasyfikacji) imion, zwłaszcza w wyznaczaniu opozycji swoje - obce, centralne - peryferyczne. Inaczej mówiąc, imię może być z jednej strony mniej lub bardziej wyrazistym znakiem przynależności grupowej, znakiem określonej kultury, z drugiej natomiast, jako przedmiot klasyfikacji i waloryzacji (waloryzacji poprzez klasyfikację), źródłem informacji o samym podmiocie dokonującym klasyfikacji (Solak 2009: 77-96).
\end{abstract}

Teoretycznie odpowiedź na pytanie, kiedy Joan (a przynajmniej niektórzy z mężczyzn noszących to imię) został Iwanem, powinny przynieść dane słownikowe - istnieją wszak co najmniej trzy słowniki imion i nazwisk bułgarskich, traktowane jako solidne kompendia naukowe: najstarszy z nich, wydany przez Bułgarską Akademię Nauk w roku 1963, Речник на личните и фамилните имена у българите Stefana Iłczewa, Nikołaja Kowaczewa Честотно-тълковен речник на личните имена у Българи (Sofia 1987) oraz dużo skromniejszy, lecz bardzo popularny Български именник Jordana Zaimowa, wydany także przez BAN w 1970 roku i wielokrotnie wznawiany. Wbrew oczekiwaniom, odpowiedzi na podobnie sformułowane pytanie nie znajdziemy w wymienionych kompendiach. Coś musiało się jednak wydarzyć, skoro Bułgarzy początkowo przejęli etymologicznie hebrajskie imię Yəhôhānān w greckiej postaci Йоан (Ншанъ), używali go przez wieki, a w pewnym momencie zrezygnowali z tej formy imienia na rzecz określanej jako bardziej „ludowa”, a przez współczesne źródła internetowe jako „bardziej słowiańska” postaci Iwan. Poza danymi historycznymi o obecności Joana w bułgarskim systemie imienniczym świadczą dziś jedynie zachowane jeszcze, ale dość rzadkie nazwiska derywowane od niego: Йоанов, Йоанова, częściej występujące w XIX wieku.

Zupełnie inaczej rzecz ma się $\mathrm{z}$ formą Iwan. Imiona Iwan, Iwanka (i pochodne od nich) oraz nazwisko Iwanow/Iwanowa są dziś zjawiskiem powszechnym. Współczesnemu użytkownikowi środków masowego przekazu, z których najczęściej czerpie się dane, trudno będzie znaleźć w nich 
np. Michaiła Joanowa, znanego w południowo-zachodniej Bułgarii działacza odrodzeniowego, który w 1873 roku założył bułgarską szkołę w Melniku. Zgodnie ze współcześnie stosowanymi antroponimami należałoby go we wszelkiego rodzaju leksykonach, zarówno tradycyjnych, jak i internetowych, szukać pod hasłem Мильо Иванов.

Tymczasem imię Joan - o czym świadczą zachowane dokumenty nosiło dziesięciu bułgarskich władców z okresu tzw. I i II państwa bułgarskiego oraz schyłku tego drugiego: Joan Władysław (1015-1018), Joan Asen (1190-1196), Joan Asen II (1218-1241), Joan Asen III (1279-1280), Joan Stefan (1330-1331), Joan Aleksander (1331-1371), Joan Asen IV (1336-1354), Joan Sziszman (1371-1395), Joan Asen V - znany także pod imieniem Jasen (1371) i wreszcie rządzący księstwem widyńskim, które najdłużej opierało się naporowi armii tureckiej, Joan Sracimir/Stracimir (1336-1396).

Bułgarscy władcy o imieniu będącym obiektem niniejszych dociekań podpisywali się zawsze grecką, a nie ludową wersją imienia, cf.: Iwan ackns (XII wiek - inskrypcja z cerkwi w Berende [Mole 1962: 39]), Iwans

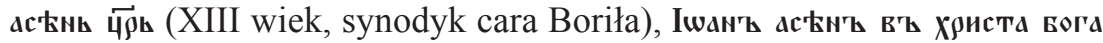
в Бљнъы царь и санодяьжєць Бльгаршнь (inskrypcja naścienna z cerkwi pw. Czterdziestu Męczenników w Tyrnowie), Iwaнъ алє̨андар (tetraewangeliarz z 1356 roku), Тш шишй цेрь с ostatni władca podpisał się pod dokumentem nadającym przywileje klasztorowi położonemu u stóp Witoszy (tzw. Витошка горамота) jako IG)

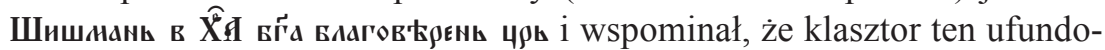

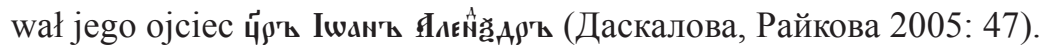

Takie same formy imion władców notuje pierwszy bułgarski kronikarz, mnich Paisij Chilendarski w swojej Historii słowianobułgarskiej (1762), dziele, które zasiało ferment, przerodzony wkrótce w tzw. ruch odrodzeniowy. Paisij wyszczególnia wszelkie znane mu od czasów najdawniejszych imiona władców Bułgarii. Wśród nich znaleźli się: wymieniony jako 18 władca Ï̈анъ Владинияљъ, jako 23 władca Ïшанъ Калинанъ, jako 28 -

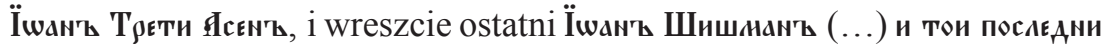
цүръ Болгарски Билъ (karta 49'). Pierwszy znany w historii Bułgarii władca o imieniu pochodzącym od ludowej/słowiańskiej formy Iwan, tj. Iwanko, pojawił się na arenie dziejowej pod koniec XII wieku i był uzurpatorem, który krótko utrzymał się u władzy (Андреев, Лаков 1996: 145-146). 
Zauważmy też, że patron Bułgarii, powszechnie znany dziś jako św. Iwan Rylski, w przeszłości nazywany był imieniem Joan. Pod tym imieniem uwiecznił go dla potomnych Władysław Gramatyk, opisując przeniesienie relikwii świętego z Tyrnowa do Riły (chociaż współcześnie tekst ten - często przerabiany w duchu „uwspółcześnienia” - publikowany jest pod różnymi tytułami, np. Разказ за пренасяне на мощчите на Иван Рилски в Рилския манастир ${ }^{1}$ lub Разказ за връщането на честните моши на преподобния наш отеи Иван от град Търново в неговата Рилска обител oraz Успение на свети Иван Рилски (Жития на българските светии, 697-720). Jeszcze osiemnastowieczny Trebnik przechowywany w bibliotece klasztornej w Rile zachował grecką formę imienia i na kartach 142a-156b opisywany jest Параклист Рылскон8 (Райков, Кодов, Христова 1986: 81), ale XIX wiek przynosi duże zmiany. Obecnie nawet najlepsze kompendia naukowe przytaczają tylko współczesną, potoczną wersję tytułu tego dzieła (Рилска повест), a w najlepszym wypadku podaną wyżej wersję tłumaczoną na współczesną bułgarszczyznę ze zmienioną formą imienia: Разказ за пренасяне мошите на Иван Рилски в Рилският манастир (Петканова 2003: 101).

Dzisiaj imię Iwan jest jednym z najpopularniejszych. Portal internetowy utworzony w celu przekazywania najbardziej aktualnych informacji (<www.vesti.bg $>$ ), powołując się na dane Narodowego Instytutu Statystycznego podaje, że według statystyk z 3 stycznia 2014 roku imię Iwan nosiło 168 tys. Bułgarów, co czyniło je drugim wśród najpopularniejszych antroponimów (pierwsze miejsce w statystykach zajmował Georgi - 173 tys. mężczyzn). Wśród nowo narodzonych obywateli Bułgarii imię Iwan otrzymało w 2013 roku 770 chłopców - częstszy obecnie okazał się tylko Martin (933 noworodki). Także żeńska forma tego imienia (Iwanka) była w ostatnich dziesięcioleciach bardzo popularna (takie imię nosi dziś 65 tys. Bułgarek), jednak obecnie nie notuje się go nawet wśród pierwszej dziesiątki imion nadawanych noworodkom². Dodać w tym miejscu nale-

\footnotetext{
${ }^{1}$ Bułgarska biblioteka wirtualna „Словото” (<www.slovoto.bg>, 17.06.2014) publikuje tekst ,testamentu” świętego z Riły zatytułowany Заветът на Свети Йоан Рилски към неговите ученици, ale jednocześnie zupełnie niekonsekwentnie piętnastowieczne dzieło Władysława Gramatyka tytułuje Разказ за пренасяне на мощите на Иван Рилски в Рилския манастир.

${ }^{2}$ Co być może jest efektem utrzymującego się od lat spadku dzietności i ma związek z tradycją, która każe nadawać potomkom imiona dziadków, przy czym zawsze preferowani
} 
ży, że także nazwisko Iwanow jest jednym z najbardziej typowych (jeśli nie najpopularniejszym - przed Georgiew - na co wskazują np. książki telefoniczne i internetowe wykazy nazwisk abonentów telefonii komórkowych).

Български именник Jordana Zaimowa (Заимов 1970: 110-111) podaje, że imię Iwan weszło do bułgarskiego przez grecki, odpowiada hebrajskiemu „bóg jest miłosierny” i zostało odnotowane w tekstach źródłowych po raz pierwszy $\mathrm{w} X$ wieku³ . Taką samą etymologię podaje macedoński Речкик на личните имиња кај македонците, datując wszakże pojawienie się formy Iwan na wiek XI (Станковска 1992: 99). Zarówno Zaimow, jak i Stankowska wskazują wiele derywatów utworzonych od tego imienia (w macedońskim słowniku także te, utworzone od nieznanej bułgarszczyźnie formy Jowan) - niektóre są bardzo rzadkie - i podają ich skrótowe objaśnienia, przytaczając analogie do innych imion, tworzonych według tego samego modelu, tutaj pominiętych (cyt. za Zaimowem w kolejności alfabetycznej):

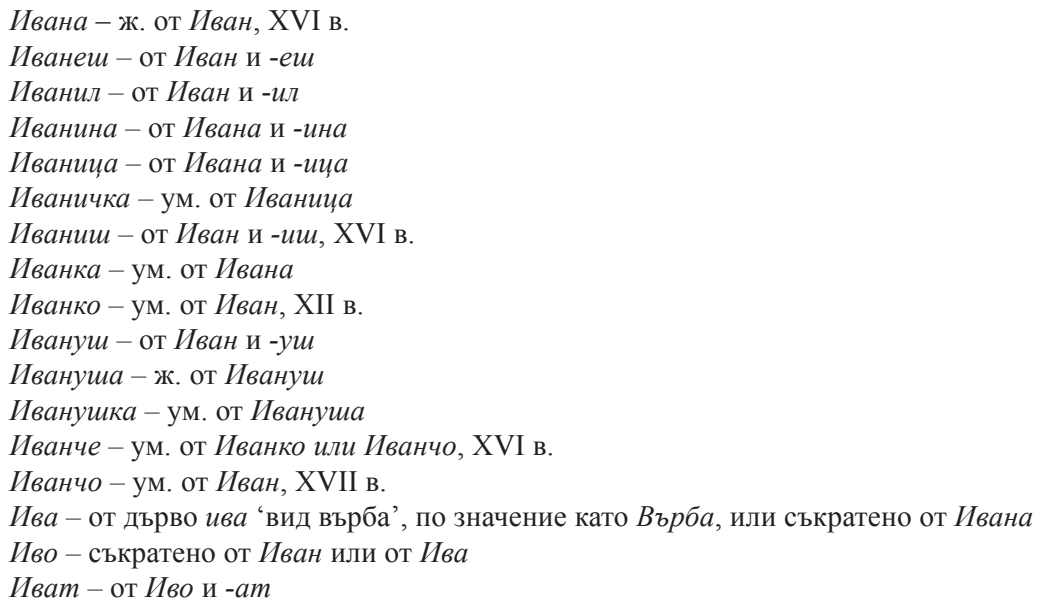

są dziadkowie w linii męskiej. Może być to także uboczny efekt europeizacji i ulegania modzie na określone imiona.

${ }^{3}$ Zaimow pisze wprawdzie we wstępie, że datację pojawienia się imion opiera na źródłach pisanych, jednak nigdzie tych źródeł nie przytacza. Zresztą niektóre z podawanych przez niego datacji stoją ze sobą (oraz domniemaną etymologią imion) w sprzeczności, co jest wyraźnie dostrzegalne w przytoczonym w tekście wykazie. 


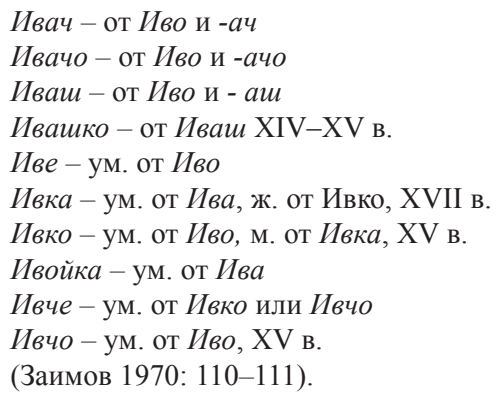

Warto dodać także skrócone formy imienia:

Вана - съкратено от Ивана

Вано - съкратено от Иван, XVI в.

(Заимов 1970: 43).

Wiele popularnych, w przeszłości i współcześnie, ludowych form od imienia Iwan uformowano także od jego zdrobniałych form, co poświadcza słownik Zaimowa. Znajdujemy wśród nich (w kolejności alfabetycznej):

Ванка - ум. от Вана или съкратено от Иванка, ж. от Ванко

Ванко - ум. от Вано или съкратено от Иванко, м. от Ванка, XVI в.

Ванкуш - от Ванко и -уш

Ванкуша - ж. от Ванко

(Заимов 1970: 43).

Dalej Zaimow przytacza licznie także inne derywaty w formie rodzaju męskiego lub żeńskiego, takie jak: Вануй, Вануйко, Вануш, Вануша, Ванушка, Ванушко, Ванцо, Ванча, Ванче, Ванчел, Ванчо, Ваньо, Ваню i wreszcie Ваня - dość częste do dziś imię żeńskie, będące derywatem od Iwan. Wszystkie one stanowią dowód na ludową proweniencję imienia Iwan i jego familiarne użycie.

Co zatem stało się z oficjalną, przejętą z greki, postacią tego imienia, dlaczego i kiedy zaniechano użycia formy Joan, a średniowieczni bułgarscy władcy wraz ze Świętym Joanem Rylskim stali się Iwanami? Z problemem tym zdają się dziś borykać wydawcy wielu współczesnych kompendiów (wyżej wspomniano już, że nawet popularna bułgarska biblioteka wirtualna <www.slovoto.bg>, międzynarodowe i powszechnie wykorzystywane źródło informacji na temat literatury bułgarskiej, nie 
potrafi zachować konsekwencji - cf. hasło Йоан Рилски w spisie autorów oraz tytuł jego dzieła, podany wprawdzie w uwspółcześnionej wersji, ale z zachowaniem starej formy imienia - Заветът на Свети Йоан Рилски към неговите ученици оraz tytuł przytoczonego wyżej dzieła Władysława Gramatyka piętnastowiecznego pisarza, z uwspółcześnioną formą Iwan: Разказ за пренасяне на мощчите на Иван Рилски в Рилския манастир).

Wydawać by się mogło, że ostoją tradycji pozostanie nadal Cerkiew, wszak nigdy nie zmieniono antroponimów np. Jana Chrzciciela (Йоан Кръстител, Йоан Предтеча) czy Jana Chryzostoma (Йоан Златоуст). Okazuje się jednak, że z wyborem odpowiedniej formy imienia mają też kłopot wydawnictwa cerkiewne. Najnowszy zbiór żywotów bułgarskich świętych wydany przez monaster Zograf na św. Górze Athos wymienia wprawdzie kilku świętych o imieniu Joan, a w zasadzie Ioan (Иоан Български, мъченик; Иоан Владимир, княз; Иоан Кукузел, преподобни; Иоан Търновски, мъченик), ale jednocześnie pisze o św. Iwanie Rylskim i oprócz żywotu zamieszcza teksty dodatkowe, zatytułowane Разказ за връщането на честните мощи на преподобния наш отец Иван от град Търново в неговата Рилска обител oraz Успение на свети Иван Рилски (Жития на българските светии, 2002). Podobne zróżnicowanie form występuje $\mathrm{w}$ pochodzącym $\mathrm{z}$ połowy lat dziewięćdziesiątych XX wieku, obszernym dwutomowym oficjalnym wydaniu żywotów świętych Bułgarskiej Autokefalicznej Cerkwi Prawosławnej, noszącym imprimatur patriarchy Maksyma (Жития на светиите, s.l., s.a.): znajdziemy tam żywoty 18 świętych o imieniu Joan (w tym Joana Władimira, kanonizowanego władcę, którego wszystkie ,świeckie” kompendia historyczne nazywają zgodnie Iwanem Władimirem), ale na próżno szukać tam Joana Rylskiego. W spisie treści, w którym zresztą litera I i J traktowane są wspólnie, pod hasłem „Joan Rylski” umieszczono jedynie odsyłacz do hasła „Iwan Rylski”.

Paradoksalnie żadnych rozterek związanych $\mathrm{z}$ formą imienia tego świętego nie mają oficjalne cerkiewne media internetowe. W kalendarzu cerkiewnym publikowanym na oficjalnej stronie internetowej Patriarchatu Bułgarskiego pod datą 18 sierpnia znajdziemy Успение на преп. Йоан Рилски Чудотворец, 19 października upamiętnia się datę odnalezienia relikwii świętego (dzień ten nazwany jest po prostu Преп. Йоан Рилски 
Чудотвореи), święto obchodzone zaś 1 lipca nosi nazwę Възвръщане честните мощи на преп. Йоан Рилски чудотворец.

Wszystko wskazuje więc na to, że ostateczne przemianowanie Joana w Iwana nastąpiło w XIX wieku, ale nie objęło swym zasięgiem wszystkich osób noszących to imię. Dlaczego zatem niektórzy zostali na trwałe „przemianowani”? Wydaje się, że przyczyn należy szukać w polityce językowej (i nie tylko językowej) doby odrodzenia narodowego. Nowobułgarski język literacki miał mieć podstawę ludową, dialektalną, nie mieściły się w nim więc, a przynajmniej z trudem znajdowały swoje miejsce, elementy obce, a za takie należy uznać greckie formy imion własnych. Silnie antygreckie nastroje tamtych czasów kazały więc „,przechrzcić” najważniejsze postaci z dziejów Bułgarii, pozostawiając grecką formę imienia tylko postaciom mniej popularnym, mniej znanym czy związanym wyłącznie $\mathrm{z}$ religią. Było to tym łatwiejsze, że ówczesna waloryzująca interpretacja form imion własnych zbiegała się w czasie z intensywną działalnością naukową i publikacyjną pierwszych bułgarskich badaczy historii i języka, którzy zdobywali wykształcenie głównie na uniwersytetach rosyjskich, a przywykłszy tam do formy „Iwan”, przyczynili się do jej popularyzacji w Bułgarii.

Zresztą do dziś w bułgarskiej onomastyce funkcjonuje tradycyjny podział osobowych imion własnych na rodzime (домашни) i zapożyczone (чужди), równoznaczny z odróżnieniem imion bułgarskich od imion Bułgarów. Jest to klasyfikacja odwołująca się do pojęcia języka etnicznego jako kategorii centrum, rozpowszechniona przez przytaczane wyżej prace Nikołaja Kowaczewa i Stefana Iłczewa (Solak 2009: 78). Nadal też funkcjonuje stereotyp Greka, obecny w przysłowiach odnotowanych w słowniku Najdera Gerowa, w których Grek jawi się jak wilk, kłamca sprawniejszy od Cygana, powodujący, że tam, gdzie stąpnie, nie rośnie nawet trawa (Геров 1976: 191).

Dylematy nazewnicze z okresu stanowienia i utwierdzania nowobułgarskiego języka literackiego znajdują swoje odzwierciedlenie na kartach powieści o tematyce historycznej. Autorzy tych utworów każdorazowo dokonują wyborów między prawdą historyczną i aktualną polityką językową, dostosowując imiona władców do wymogów czasów, w których powstały poszczególne dzieła. W czasach najgorętszego zwalczania grecyzmów stosują zatem ludową formę imienia Iwan i konsekwentnie piszą o Iwanie 
Sziszmanie oraz Iwanie Aleksandrze (cf. Luben Karawełow, Отмъщение, После отмъщението, Тука му е краят, trylogia z lat 1873-1874; Nikoła Naczow, На Царевеu, 1907 - autorzy tych powieści używają wyłącznie formy Иван Шишман; podobnie postępuje Iwan [sic!] Wazow, piszący w 1906 roku powieść o Iwanie Aleksandrze, w której stosuje formę imienia cara użytą w tytule - Иван-Александър).

Po wojnach bałkańskich sytuacja się zmienia i autorzy powieści historycznych znów powracają do tradycyjnej formy imienia władców (Stojan Zagorczinow, Ден последен - ден господен, 1931-1934, występuje tu Йоан-Александър czy Fani Popowa-Mutafowa, Йоан Асен II, 1938, konsekwentnie posługująca się imieniem władcy wymienionym w tytule).

W powieściach o tematyce historycznej powstałych po 1944 roku nie możemy się już niestety doszukać żadnej reguły. Autorzy dzieł z tego okresu stosują zarówno tradycyjną, grecką, jak i popularniejszą (bardziej rozpowszechnioną przez podręczniki historii, prasę itp.) formę imienia władców (Dymitr Mantow, Иван Асен II изар и самодържец, 1960; роdobnie postępują: Wera Mutafczijewa, używając w powieści Последните Шиимановци z 1969 roku antroponimów Иван-Александър і Иван Шишман, Slav Chr. Karasławow w tetralogii z lat 1970-1976 И се възвисиха Асеновци oraz Emilian Stanew, autor powieści Антихрист z roku1970, w której występują Иван-Александър і Иван Срацимир).

W latach siedemdziesiątych XX wieku następuje powrót do pierwotnej formy imienia i kolejni twórcy piszący powieści historyczne w tytułach swoich utworów umieszczają imię Joan (Ewgeni Konstantinow, Cваmбите на Йоан Асен, 1974; Boris Brajkow, И живя в мир владетейят Йоан Асен II, 1977; Iwan Trenew, Наследниите на Иван Асен II, 1987). Przykłady tego typu można by mnożyć. Współczesny Bułgar może się zatem dziwić, podobnie jak moja znajoma, wspomniana na wstępie, że carowie władający krajem, a nawet jego święty patron, w przeszłości nazywani byli inaczej niż obecnie. Mając jednak na względzie skomplikowane losy bułgarskiego języka literackiego, podejmowane w XIX wieku próby oczyszczenia go nie tylko z licznych naleciałości orientalnych, ale także greckich, starania prowadzące do zastąpienia wszelkich obcych wyrazów (także antroponimów) formami ludowymi, wpływy języka rosyjskiego i nawyki nazewnicze językoznawców, którzy kolejne stopnie naukowe zdobywali na rosyjskich uczelniach, nie powinniśmy się temu dziwić. 
Uznajmy zatem za przejaw normalizacji języka fakt, że średniowieczni bułgarscy władcy, jakiekolwiek imię otrzymaliby na chrzcie, zostali przez współczesną historiografię przemianowani i noszą dziś swojsko brzmiące imię Iwan: wszak rodzimy władca musi nosić rodzime imię (co najmniej od połowy XIX wieku). Z tego samego powodu nie dziwmy się, że przemianowano także patrona Bułgarii. Zmiana ta zresztą wydaje się trwała, bo kolejne pokolenia wychowane na podręcznikach, które tylko taką formę stosują, za jakiś czas nie będą się już zastanawiały nad pytaniem zawartym w tytule niniejszego artykułu.

\section{Literatura}

Mole W., 1962, Sztuka Stowian południowych, Wrocław-Warszawa-Kraków.

Solak E., 2009, Znaki szczególne. Językowe $i$ wokótjęzykowe problemy bułgarskiego Odrodzenia, Kraków.

Андреев Й., Лаков М., 1996, Българските ханове и иаре, Велико Търново. Даскалова А., Райкова М., 2005, Грамоти на българските изаре. Увод. Текстове.

Речник. Библиография, София.

Геров Н., 1976, Речник на българския език, т. 1, София.

Илчев С., 1963, Речник на личните и фамилните имена у българите, София.

Ковачев Н., 1987, Честотно-тълковен речник на личните имена у Българи, София.

Петканова Д. (съст.), 2003, Старобългарска литература. Енциклопедичен речник, Велико Тьрново.

Райков Б., Кодов Х., Христова Б. (ред.), 1986, Славянски ръкописи в Рилския манастир, t. 1, София.

Станковска Љ., 1992, Речкик на личните имиға кај македонщите, Скопје. Заимов Й., 1970, Български именник, София.

Жития на българските светии. Съдържа 64 жития на светии, почитани по българските земи, 2002, Света Гора Атон, Славянобългарски манастир „Св. Вмчк Георги Зограф".

Жития на светиите, съст. авторски колектив, t. 1, s.a., s.1.

Źródła internetowe

$<$ www.vesti.bg>, 9.04.2014.

$<$ www.slovoto.bg>, 9.04.2014.

$<$ www.patriarsha.bg/ calendar.php>, 9.04.2014. 